\title{
Learners' Beliefs About Language Learning: A Factorial Investigation
}

\section{Christopher Pirotto \\ Fukui University of Technology}

\section{Reference Data:}

Pirotto, C. (2019). Learners' beliefs about language learning: A factorial investigation. In P. Clements, A. Krause, \& P. Bennett (Eds.), Diversity and inclusion. Tokyo: JALT.

It is important for language instructors to understand the language learning beliefs of their students. A language learner's beliefs about how a language should be learned can cause learners to question the teaching ability of their language instructors. In this paper, are presented the results of an investigation to identify the language learning beliefs of Japanese university EFL students. Data was collected from 206 individuals using Horwitz's (2013) Beliefs About Language Learning Inventory (BALLI) questionnaire. Exploratory factor analysis (EFA) was used to identify 6 commonly held beliefs about language learning. These 6 beliefs are presented along with a discussion about how the instructor used these beliefs to implement change in the classroom.

語学教員として大切なことは言語学習者のビリーフ(言語学習観、信念)を理解することだ。言語学習者のビリーフにお いて、どのように言語を学習するべきかという点で、学習者が、語学教員の指導能力を疑問視することが起こりうる。したが つて、本論文では、英語学習をしている日本人学生の学習者のビリーフをつきとめるための調査結果を報告する。調査デ 一タは、206名からHorwitz's (2013) Beliefs about Language Learning Inventory (BALLI) のアンケートを使用して收集し た。Exploratory Factor Analysis (EFA) は言語学習において一般的に6つのビリーフがあることを明らかにした。その6つのビリ 一フをどのように教員が取り入れたら授業が变わるのかを協議しながら提示する。

$\mathrm{n}$ Japanese junior and senior high schools, grammar-translation is traditionally the most used English language teaching method due to the importance of university admission exams (O’Donnell, 2005). Learners who graduate from senior high school and enter university English programs focused on developing communicative skills may begin to question their language learning beliefs due to the drastic change in teaching methodology. For example, if a student who has spent years learning English from a dictionary then is forced into a project-based learning class, the student may question this new methodology. It is important that teachers be aware of the language learning beliefs their learners hold. Therefore in this study I attempted to identify the language learning beliefs of 206 Japanese university students.

I begin with a discussion on beliefs about language learning. After that, the methodology of the study will be explained and the results from a questionnaire given to participants will be presented. Finally, there will be a discussion about how I used the results to implement change in the classroom.

\section{Language Learning Beliefs}

Elaine Horwitz, a leading researcher on learner beliefs, found that a language learner's beliefs about how a language is learned are affected by past experiences as well as cultural background (Horwitz, 1988). Horwitz also stated that these beliefs can then impact the learners' behavior towards learning a language. If learners' beliefs about how a language should be learned do not align with how an instructor is conducting a language class, the quality of the instructor may then be questioned and the students' motivation to participate in class or learn a language may decrease.

In addition, the language learning beliefs of an individual will directly affect the success of the individual in learning a new language. The strategies implemented by students to learn a new language are influenced by their language learning beliefs (Yang, 1999). Ariogul, Unal, and Onursal (2009) found that for their students, certain beliefs were detrimental to long-term language learning success. Therefore, it is very important for teachers to be aware of the beliefs their students hold and how these beliefs may impact their students.

Language learning beliefs, or learner beliefs, have been researched by many scholars. However, there does not seem to be a consensus definition. Horwitz tends to describe learner beliefs in her research as preconceived ideas that are rather stable and 
unchanging (Horwitz, 1987). However, Hosenfeld (2003) stated that beliefs are formed by experiences and are constantly changing. Hong (2006) pointed out that beliefs can be defined as ideas, assumptions, knowledge, philosophies, or values in relation to language learning. Researchers of learner beliefs may adjust their investigation based on how they choose to define learner beliefs. In this paper, I will use the same definition that Horwitz (1987) and Miller and Ginsbert (1995) used and define learner beliefs as ideas that students have about language learning. This is a broad, easily definable, and easily understandable definition.

\section{Research Questions}

This study had two research questions:

RQ1. What commonly held beliefs about language learning can be identified in this group of students?

RQ2. If beliefs can be identified, can this knowledge be used to directly implement changes in the classroom?

\section{Methodology}

\section{Participants}

The participants of this study were 206 students from a rural Japanese private university. They varied in academic majors and ranged from 1st- to 3rd-year students. Four years of English language courses that are focused on improving students' oral communication skills are compulsory for all students at this university. Consent from the university administration was received to survey and interview students.

\section{Instrument}

This study adopted the Beliefs About Language Learning Inventory (BALLI), created by Horwitz (2013). The decision to use the BALLI was made because the BALLI was designed to test various aspects of language learning beliefs such as the difficulty of language learning, the nature of language learning, foreign language aptitude, learning strategies, and motivation or expectations.

The extent that the BALLI has been used to investigate learner beliefs only adds value to its usage as an instrument. For an extensive review of studies that have used the BALLI, see Hong (2006). After looking at many studies that used the BALLI, Hong found that the reliability of the BALLI questionnaires usually ranged from a 0.59 to 0.71 Cronbach's alpha. Any value less than 0.60 is considered poor, greater than 0.70 is acceptable, and in between values are questionable. Despite researchers commonly reporting poor or questionable Cronbach alpha values from the BALLI, Hong argued that this is perfectly acceptable due to the nature and design of the BALLI (pg. 72).

For this study I used Horwitz's (2013) 2.0 version of the survey, which was designed specifically for students of English as a second or foreign language. Some items were altered or deleted to properly fit the teaching context and the students it would be administered to. For example, "People in my country" was rewritten to read "Japanese (people)." The questionnaire was then translated into Japanese and back-translated into English by two native-Japanese bilinguals to ensure correct translation. It was then piloted on a group of eight adult English language learners with a discussion about each question to confirm that each question was testing the intended concept. The final version of the questionnaire, included in the Appendix, was given to all 206 university students. It consisted of 40 Likert items with possible responses ranging from 1 (strongly disagree) to 5 (strongly agree).

\section{Interviews}

Open-ended interviews with six participants were conducted after the data analysis was complete. Interviews were conducted on campus, in a public setting, and in the language that the interviewee was most comfortable with. Three males and three females participated in the interviews. Students were selected because of their varying English abilities and their varying motivation levels, as seen from the instructor's perspective. As this paper is a part of a larger research project, the purpose of the interviews was to confirm that what the quantitative data is saying might be true and worthy of a future more in-depth qualitative study.

\section{Data Collection}

The questionnaire was explained and administered at the same time as the participants' midterm tests. Students were informed that this questionnaire was for their instructor's research purposes, was completely optional and anonymous and had no effect on their class grades. Students were also instructed to place the questionnaire in a manila envelope, completed or not, at the time that they submitted their midterms. This allowed the students to have full confidence that it was optional and anonymous. 


\section{Data Analysis}

All responses from the questionnaires were input into SPSS 24. Investigations into learner beliefs consisting of a large amount of survey data are specifically mentioned by Loewen and Gonulal (2015) as an example for which factor analysis would be an appropriate quantitative method to "investigate the correlations present in the data and to consolidate variables in a principled manner" (p. 183). Therefore, in this study, an exploratory factor analysis (EFA) was run to identify the most widely held underlying factors of learners' beliefs present in the questionnaire data.

The reason to use an EFA, as opposed to a confirmatory factor analysis (CFA), was that there was no prior knowledge of what the participants believed or expectations of how they would respond. The type of EFA used was principal axis factoring (PAF) since PAF produces better solutions and is better for understanding the structure of the data, whereas the main use of principal component analysis (PCA) is to explain the variances of the measured variables (Loewen \& Gonulal, 2015).

An oblique rotation was applied to make the results more interpretable. This was chosen over an orthogonal rotation because orthogonal rotations assume there are no correlations between factors, which is usually not a safe assumption to make in language learning (Loewen \& Gonulal, 2015, p. 197). Because Brown (2016) stated that factor loadings of less than 0.30 are usually ignored completely (p. 240) and Pett, Lackey, and Sullivan (as cited in Loewen \& Gonulal, 2015) stated that factor loadings less than 0.40 can be ignored (p. 199), a middle ground of 0.35 or greater were considered significant for this study.

\section{Results}

The results of the initial EFA produced 12 factors with eigenvalues over 1.0 (the default threshold to determine the number of factors) and an overall Cronbach's alpha of 0.68 , which signifies questionable internal reliability. However, after examining the communalities, 11 questions were removed from the analysis. It should be noted that the data from these questions are still reported and discussed when appropriate in this paper. However, including questions that are not correlated with other questionnaire items would make the factor analysis more complicated and difficult to interpret. In addition, removing these questions gives the analysis a more appropriate participant-item ratio of 7-to-1.
After the 11 questions were removed, the analysis produced 10 factors with eigenvalues over 1.0 with a Cronbach's alpha of .70. However, after analyzing the scree plot, it was determined that a 6 -factor solution would be most appropriate, accounting for $45 \%$ of the variance. These results can be seen in Table 1, along with the mean and standard deviation of each item in the six factors. It should be noted that the KaiserMeyer-Olkin (KMO) score was $0.666 \mathrm{~m}$, which signifies mediocre sample adequacy (Field, 2009, p. 679); Bartlett's Test of Sphericity proved significant at .000, providing evidence that correlations were present; and the correlation matrix was checked for multicollinearity and none was found. All of this provides evidence that the results can be accepted as assumptions have been addressed.

\section{Interpretation of Factors}

As seen in Table 1, Motivations Stemming From Globalization is the title of the first factor. While this factor does not address how a language is learned, it is an important factor to understand why English is being or should be learned. It contains items regarding the desire to speak English well, to have better future opportunities, and to meet English speakers. Students overwhelmingly agreed with such statements. This was confirmed in follow-up interviews as several students stated that their motivation for learning English stems from reasons such as it is required to secure a job at major corporations, there is an increasing population of foreigners in Japan, and there are increasing opportunities to travel overseas. All these answers lead to the conclusion that students' motivation or desire to learn English stems from globalization.

The second factor, Equality in Language Learning, consists of questions related to the language learning ability of certain types of individuals. Participants remained neutral, not favoring women over men or technical majors over other majors. In addition, there was no agreement regarding certain learners having a special ability to learn English and participants even felt that learners who made past mistakes could correct their mistakes. Student interviewees explained that anyone who makes an effort to learn English can learn English given they have opportunities and resources to study. It is safe to conclude that this group of students did not feel that certain groups of individuals are disadvantaged when it comes to learning English. 


\begin{tabular}{llllllll} 
Table 1. Rotated Factor Loadings \\
\cline { 2 - 8 } Items & \multicolumn{7}{c}{ Factors } \\
\hline
\end{tabular}

I. Motivations Stemming From Globalization

3) It is necessary to know about Englishspeaking countries.

15) I would like to learn English so that I can get to know English speakers.

25) I would like to have English speaking friends.

5) If I learn to speak English very well, I will have better opportunities for a good job.

10) I want to speak English well.

$3.97 / 0.94 \quad .74$

$3.43 / 0.96 \quad .73$

$3.64 / 1.00$

$4.11 / 0.93 \quad .50$

$4.17 / 0.89$

II. Equality in Language Learning

24) If beginning students are permitted to make $2.62 / 0.91$ errors in English, it will be difficult for them to speak correctly later.

26) Women are better than men at learning

$2.57 / 0.94$

English

29) People who are good at Math and Science are not good at learning English.

6) Some people have a special ability for $\quad 284 / 1.19$

learning English.

III. Importance of Native Speaker Input

23) It is better to have teachers who are native- $\quad 3.75 / 0.88$ speakers of English.

9) You shouldn't say anything in English until you can say it correctly.

8) It is best to learn English in an English- $\quad 3.96 / 0.97$ speaking country.

28) It is important to use various forms of multimedia to learn English.

\begin{tabular}{|c|c|c|c|c|c|c|c|}
\hline \multirow[b]{2}{*}{ Items } & \multicolumn{7}{|c|}{ Factors } \\
\hline & Mean/SD & 1 & 2 & 3 & 4 & 5 & 6 \\
\hline \multicolumn{8}{|l|}{ IV. Lack of Confidence in Language Learning } \\
\hline $\begin{array}{l}\text { 7) I believe that I will learn to speak English } \\
\text { very well. }\end{array}$ & $2.55 / 0.86$ & & & & .74 & & \\
\hline 21) I have a special ability for learning English. & $2.04 / 0.83$ & & & & .69 & & \\
\hline 11) Japanese are good at learning English. & $2.33 / 0.78$ & & & & .40 & & \\
\hline 22) English is a difficult language. & $3.56 / 0.97$ & & & & -.39 & & \\
\hline \multicolumn{8}{|l|}{ V. Importance of a Comprehensible Accent } \\
\hline $\begin{array}{l}\text { 37) It is important to speak like a native } \\
\text { speaker. }\end{array}$ & $2.97 / 0.97$ & & & & & .87 & \\
\hline $\begin{array}{l}\text { 4) It is important to speak with an excellent } \\
\text { accent. }\end{array}$ & $3.88 / 1.06$ & & & & & .56 & \\
\hline \multicolumn{8}{|l|}{ VI. Importance of Vocab and Grammar } \\
\hline $\begin{array}{l}\text { 18) The most important part of learning } \\
\text { English is learning vocabulary words. }\end{array}$ & $3.58 / 0.94$ & & & & & & .56 \\
\hline $\begin{array}{l}\text { 17) It is easier to read and write English than to } \\
\text { speak and understand it. }\end{array}$ & $3.01 / 1.11$ & & & & & & .50 \\
\hline $\begin{array}{l}\text { 27) The most important part of learning } \\
\text { English is learning the grammar. }\end{array}$ & $3.06 / 1.00$ & & & & & & .38 \\
\hline
\end{tabular}

The third factor, which is labeled Importance of Native Speaker Input, showed that there is a clear favorability towards receiving input from native speakers, whether it be in an English-speaking country, in the classroom, or from various radio or TV programs. The addition of one item in this factor, "You shouldn't say anything in English until you can say it correctly," which was strongly disagreed to by the participants, may seem out of place but it will become clear later during an analysis of the interviews. One student explained that any opportunity to speak with native speakers should be taken, even if you make mistakes. Another interviewee reported this controversial belief: "Native speakers speak real English; therefore, you should attempt to speak with them even if communication is rough."

Factor 4 is titled Lack of Confidence in Language Learning. This factor had most participants responding that English was a tough language, they did not have a special 
ability to learn English, and that they will probably not become able to speak English well. In addition, despite their feelings about equality in Factor 2, participants felt that Japanese people were not good at learning English. Two interviewees pointed out that they had been studying since elementary school but did not feel like they had progressed, hence the belief that they will not learn to speak English well.

Factor 5 is Importance of a Comprehensible Accent. Participants felt that it was important to speak with an excellent accent, but they neither agreed nor disagreed that the accent needed to be just like that of a native speaker. Five of the six interviewees mentioned that an excellent accent is important so listeners can comprehend, but they also expressed that it would be near impossible to speak just like a native speaker.

The sixth and final factor is Importance of Vocabulary and Grammar. In this factor the students reported that the most important thing about learning English is to learn vocabulary. In addition, a good number of students responded that they were more comfortable with reading and writing than speaking and listening. This result is not surprising as the Japanese secondary school system heavily emphasizes the grammartranslation method of teaching English.

\section{Select Descriptive Statistics}

Since factor analysis looks for groupings of items that are correlated with each other, it leaves out items which have no correlation with other items. Therefore, it is also important to look at how participants responded to the questionnaire items that were not included in the 6 -factor solution found in Table 1, as these items too will provide insight into the beliefs of learners. The descriptive statistics for all of these items are shown in Table 2.

Some of the questions that are similar to the results found in the factor analysis include agreement with "Everyone can learn English" (Q32), "It is OK to guess if you don't know a word" (Q14), and "Japanese people feel that it is important to speak English" (Q20).

Students were unable to express collective agreement over the statements such as "I can learn a lot from nonnative English teachers" (Q30), "I can learn a lot from group activities with other students in my English class" (Q31), and "It is possible to learn English on your own without a teacher or class" (Q34). Question 31 is intriguing due to the participants' strong agreement with "It is a good idea to practice speaking with other people who are learning English" (Q19), implying that the participants felt that they could learn from other English language learners as long as those learners were not their classmates.
Table 2. Descriptive Statistics of Remaining Items

\begin{tabular}{lcc}
\hline Items & Mean & SD \\
\hline 1) It is easier for children than adults to learn English. & 3.87 & 0.98 \\
2) Some languages are easier to learn than others. & 3.73 & 0.93 \\
12) It is easier to speak than understand English & 3.13 & 0.91 \\
13) In order to speak English, you have to think in English. & 3.02 & 0.98 \\
14) It is OK to guess if you don't know a word in English. & 3.51 & 0.96 \\
16) It is easier for someone who already speaks a foreign language to & 3.53 & 0.89
\end{tabular}
learn another one.

19) It is a good idea to practice speaking with other people who are earning English.

20) Japanese people feel that it is important to speak English.

30) I can learn a lot from non-native English teachers.

31) I can learn a lot from group activities with other students in my

English class.

32) Everyone can learn to speak English.

33) Learning English is different from learning other subjects.

34) It is possible to learn English on your own without a teacher or class.

35) The most important part of learning English is learning how to translate from Japanese.

36) I can find a lot of useful materials to practice English on the Internet.

38) I feel shy speaking English with other people.

39) Tests like the TOEIC, TOEFL, or EIKEN are good tests of my English ability.

2.54 


\section{Discussion of Implemented Changes}

With the knowledge gained about this group of learners, we were able to implement changes in the classroom. The effectiveness or impact of such changes has not yet been measured. Factor 1 led to the realization that this group of learners has a real interest to learn about other people and cultures. Therefore, conversations have begun with faculty members at institutions abroad about implementing a pilot pen-pal type exchange so students can learn about the life of students in other countries.

Student response to Factor 3 led to a conscious effort to introduce a much wider rang of media to the class, especially to rely not only on the assigned textbook. This includes introducing video clips, Internet stories, comics, Twitter, and the news to the classroom. Also, the instructors have begun showing more examples of nonnative English speakers using English at a native-like level, hoping to convince the learners that nonnative speakers of English can contribute just as much as native speakers to the languagelearning process.

Analysis of Factor 4 led to a realization that more encouragement is necessary for the students and that they may require evidence that their English is improving. Therefore, since this specific English program is 4 years in length, methods to track students' improvement have been implemented. This includes multiple modes of assessment such as the CEFR-J and TOEIC Bridge. Results will be added to the newly created student portfolios that students will receive at the beginning of each semester, which will help show students their progress through the program. In addition, writing journals have been implemented so students can compare current writing with earlier writing.

With the belief that pronunciation, grammar, and vocabulary are important (Factors 5 and 6), the instructor has begun to put more emphasis on pronunciation practice on each unit's keywords and important phrases. These keywords and phrases are tested in the first 5 minutes of each class with a short quiz, providing students with evidence that their instructor is taking their learning of vocabulary and grammar seriously and not just focusing on conversation.

\section{Conclusion}

The main conclusion from this study is that instructors should be aware of the beliefs their students hold. This allows the instructor to tailor the learning process to the needs and wants of the learners, which in theory will further increase the motivation of the students and the perceived reputation of the instructor. However, it is important to keep in mind that each teaching context is different and each group of learners is different.
Therefore, rather than applying the results of this study to a different group of learners, it may be better to use this study as one example of how to investigate the language learning beliefs of language learners.

Bio Data

Christopher Pirotto is an assistant professor at Fukui University of Technology. His research interests include language learning anxiety, language learning beliefs, and quantitative research methods. <chris.pirotto@fukui-ut.ac.jp>

\section{References}

Ariogul, S., Unal, D. C., \& Onursal, I. (2009). Foreign language learners' beliefs about language learning: a study on Turkish university students. Procedia Social and Behavioral Sciences, 1, 1500 1506. https://doi.org/10.1016/j.sbspro.2009.01.265

Brown, J. D. (2016). Statistics corner: Questions and answers about language testing statistics. Tokyo: JALT Testing and Evaluation SIG.

Field, A. (2009). Discovering statistics using SPSS. London, England: Sage.

Hong, K. (2006). Beliefs about language learning and language learning strategy use in an EFL context a comparison study of monolingual Korean and bilingual Korean-Chinese university students (Doctoral dissertation). Retrieved from https://digital.library.unt.edu/ark:/67531/metadc5270/ m2/1/high_res_d/dissertation.pdf

Horwitz, E. K. (1987). Surveying student beliefs about language learning. In A. Wenden \& J. Rubin (Eds.), Learner strategies in language learning (pp. 119-129). Englewood Cliffs, NJ: Prentice Hall International.

Horwitz, E. K. (1988). The beliefs about language learning of beginning university foreign language students. Modern Language Journal, 72, 283-294. https://doi.org/10.1111/j.1540-4781.1988 tb04190.x

Horwitz, E. K. (2013). Becoming a language teacher: A practical guide to second language learning and teaching. Boston, MA: Pearson Education.

Hosenfeld, C. (2003). Evidence of emergent beliefs of a second language learner: A case study. In P. Kalaja \& A. M. F. Barcelos (Eds.), Beliefs about SLA (pp. 37-54). Dordrecht, The Netherlands: Springer. https://doi.org/10.1007/978-1-4020-4751-0_2

Loewen, S., \& Gonulal, T. (2015). Exploratory factor analysis and principal components analysis. In L. Plonsky (Ed.), Advancing quantitative methods in second language research (pp. 182-212). https:// doi.org/10.4324/9781315870908-9 
Miller, L., \& Ginsbert, R. (1995). Folklinguistic theories of language learning. In B. Freed (Ed.), Second language acquisition in a study abroad context (pp. 293-315). https://doi.org/10.1075/ sibil.9.18mil

O’Donnell, K. (2005). Japanese secondary English teachers: Negotiation of educational roles in the face of curricular reform. Language, culture, and curriculum, 18(3), 300-315. https://doi. org/10.1080/07908310508668749

Yang, N. D. (1999). The relationship between EFL learners' beliefs and learning strategy use. System, 27, 515-535. https://doi.org/10.1016/S0346-251X(99)00048-2

\section{Appendix}

Survey Questions in Japanese

1. 子どもの方が、大人より英語を習得するのが簡単である。

2.いくつかの言語は他の言語よりも習得が難しい。

3. 英語を話すために、英語圏の国々について知ることは必要な事だと思う。

4. 適切な発音で英語を話すことが重要だ。

5. 英語を上手に話せるようになつたら、将来いい仕事をみつけることに結びつくと思う。

6. 生まれながらにして、英語を習得する才能を持っている人がいる。

7. 将来、自分は英語をとても上手に話せるようになると思う。

8. 英語圈の国で英語を学ぶのが最善の方法だ。

9. 正しく話せるようになるまで、英語を話すべきではないと思う。

10、私は英語を上手に話したいです。

11. 日本人は、外国語を習得するのが得意である。

12. 英語を話す方が、聞いて理解するよりも簡単だと思う。

13. 英語を話すには、英語で考える必要がある。

14. もし英語でわからない単語があったら、その意味を推測してもかまわない。

15. 英語を話している人たちのことを知ることができるので英語を学びたい。

16. 他の語学を話せる人の方が、そうでない人よりも言語を習得するのが簡単だと思う。

17. 英語を読夕書きすることの方が、話したり聞いて理解することより簡単だと思う。

18. 英語を学ぶ上で最も重要なのは、単語を学習することだ。

19. 英語を学んでいる人と話すことを練習することは良い考えだ。

20．日本人は、英語を話す事を大事だと思っている。
21. 私は英語学習という特技を持っている。

22. 英語は難しい言語だ。

23. 英語を母国語とする教師を雇う方が良い。

24. もし初めの段階で間違いを指摘されたら、その間違いを後で訂正することは難しいと思う。

25. 私は英語を話せる友達が欲しいです。

26. 女子の方が男子よりも英語を習得するのが上手である。

27. 英語を学ぶ上で、最も重要な部分は文法を学ぶことだ。

28. 音楽を聞いたり、英語のテレビを見ることは、英語を学習する上でとても重要な事である。

29. 数学や科学が得意な人は、外国語を習得するのが上手ではない。

30. 英語を第二言語とする教師からの方が多くを学ぶことができる。

31. 私は英語のクラスで他の学生やクループ活動から多くを学ぶことができる。

32. 誰でも英語を話せるまで習うことができる。

33. 英語の学習は、他の教科を学ぶ事とは異なると思う。

34. 先生やクラスなしで、自分自身で英語を学ぶことができる。

35. 英語を学ぶ上で最も重要な部分は、日本語から英語へ翻訳するかを学ぶことだ。

36. 私はインターネットで英語を練習するために役に立つ資料を多くを見つけることができる。

37. ネイティブの方のように英語を話すことが重要だ。

38. 私は他の人と英語を話す事を恥ずかしいと感じる。

39. TOEIC、TOEFL, または英検のような試験は、私の英語能力を確認するのに良い試験です。

40. 私は英語テスト (TOEIC、大学入試、期末テストなど)の準備に時間を費やしたので、実際に英 語を学ぶ時間はなかった。 